Article

\title{
Study on Sintering System of Calcium Barium Sulphoaluminate by XRD Quantitative Analysis
}

\section{Jun Chang *, Xiaopeng Shang and Jiuye Zhao}

School of Civil Engineering, Dalian University of Technology, Dalian 116024, China; E-Mails: k@bw.com (X.S.); zhaojiuye89@126.com (J.Z.)

* Author to whom correspondence should be addressed; E-Mail: mlchang@dlut.edu.cn; Tel./Fax: +86-0411-8470-7171.

Academic Editor: Wen-Hsiang Hsieh

Received: 18 August 2015 / Accepted: 20 October 2015 / Published: 2 November 2015

\begin{abstract}
Calcium barium sulphoaluminate (CBSA), derived from calcium sulphoaluminate (CSA), has excellent cementitious properties. In this study, the sintering system of CBSA with a theoretical stoichiometric $\mathrm{Ca}_{3} \mathrm{BaAl}_{6} \mathrm{SO}_{16}$ was investigated. Rietveld refinement was performed using TOPAS 4.2 software to quantitatively calculate the content of CBSA and the actual ionic site occupancy of $\mathrm{Ba}^{2+}$. The results indicate that the content of $\mathrm{Ca}_{4}-\mathrm{Ba}_{x} \mathrm{Al}_{6} \mathrm{SO}_{16}$ increases with increasing sintering temperature in the $1200-1400{ }^{\circ} \mathrm{C}$ ranges. When sintered at $1400{ }^{\circ} \mathrm{C}$ for $180 \mathrm{~min}$, the content of CBSA reaches $88.4 \%$. However, CBSA begins to decompose at $1440{ }^{\circ} \mathrm{C}$, after which the content decreases. The replacement rate of $\mathrm{Ba}^{2+}$ was also enlarged by increasing sintering temperature and prolonged sintering time. Sintering at $1400{ }^{\circ} \mathrm{C}$ for $180 \mathrm{~min}$ is considered as the optimum when replacement rate of $\mathrm{Ba}^{2+}$ and the content of CBSA were taken into account. $\mathrm{Ca}_{3.2} \mathrm{Ba}_{0.8} \mathrm{Al}_{6} \mathrm{SO}_{16}$ with a content of $88.4 \%$ was synthesized.
\end{abstract}

Keywords: calcium barium sulphoaluminate; sintering system; $\mathrm{Ba}^{2+}$ replacement rate; Rietveld refinement

\section{Introduction}

Calcium barium sulphoaluminate (CBSA), derived from calcium sulphoaluminate (CSA), is the dominant mineral of sulphoaluminate cement and plays a decisive role in the performance of sulphoaluminate cement. The mineral properties of CBSA will be improved, and thereby the 
performance of cement will also improve, when $\mathrm{Ca}$ ions are replaced by the $\mathrm{Ba}$ ions [1-4]. With the improvement of testing techniques and analysis software, Rietveld refinement can be used to study the atomic site occupancy, changes of lattice parameters, crystal structures and crystal phases during the solid solution reaction [5]. The results showed that the calcium sulphoaluminate could be cubic [6,7], tetragonal [8] and orthorhombic [9,10]. Hargis et al. refined the three crystal systems separately by Rietveld refinement and showed that the fitting result of the orthorhombic is the best [11]. Cuesta et al. indicated that CSA mineral could be orthorhombic and that orthorhombic crystal sometimes would transform into the cubic at around $470{ }^{\circ} \mathrm{C}[12,13]$. Andac et al. also showed that crystal system transition occurred at around $470{ }^{\circ} \mathrm{C}$ [14]. Pinazo quantitatively analyzed the sulphoaluminate cement with orthorhombic and cubic CSA using Rietveld refinement methods [15].

With Rietveld refinement and highly qualified XRD data, quantitative phase analysis of the sintered products and atomic occupancy of barium ions can be obtained. In this paper, 1 mol barium ions was prepared to replace the calcium ions in CSA mineral and the minerals were sintered at $1200{ }^{\circ} \mathrm{C}$, $1300{ }^{\circ} \mathrm{C}, 1350{ }^{\circ} \mathrm{C}, 1400^{\circ} \mathrm{C}$ and $1440{ }^{\circ} \mathrm{C}$, respectively, for $90 \mathrm{~min}, 120 \mathrm{~min}, 150 \mathrm{~min}$ and $180 \mathrm{~min}$. Phase identification was carried out using Diffract EVA software (Bruker AXS, Berlin, Germany). Rietveld refinement was performed using TOPAS 4.2 software (Bruker AXS, Berlin, Germany) to quantitatively calculate the content of CBSA and the ionic occupancy of $\mathrm{Ba}^{2+}$. The optimum sintering system of CBSA and the effects of which on ionic occupancy of $\mathrm{Ba}^{2+}$ were investigated.

\section{Experimental Section}

\subsection{Sample Preparation}

Analytic chemical reagents calcium carbonate $\left(\mathrm{CaCO}_{3}\right)$, anhydrite calcium sulfate $\left(\mathrm{CaSO}_{4}\right)$, barium carbonate $\left(\mathrm{BaCO}_{3}\right)$ and neutral alumina $\left(\mathrm{Al}_{2} \mathrm{O}_{3}\right)$ were used as raw materials. Quantities of $2 \mathrm{~mol} \mathrm{CaCO}_{3}$, $1 \mathrm{~mol} \mathrm{BaCO}_{3}, 3 \mathrm{~mol} \mathrm{Al}_{2} \mathrm{O}_{3}$ and $1 \mathrm{~mol}$ anhydrous $\mathrm{CaSO}_{4}$ were mixed and ground for $10 \mathrm{~min}$. Then the raw materials were pressed into round cakes $(\Phi 5 \mathrm{~cm} \times 1 \mathrm{~cm})$ and were put into a high temperature furnace for sintering. The target temperatures were $1200^{\circ} \mathrm{C}, 1300{ }^{\circ} \mathrm{C}, 1350{ }^{\circ} \mathrm{C}, 1400{ }^{\circ} \mathrm{C}$ and $1440{ }^{\circ} \mathrm{C}$, respectively. The prolonged sintering time for each temperature was $90 \mathrm{~min}, 120 \mathrm{~min}, 150 \mathrm{~min}$ and $180 \mathrm{~min}$. The minerals were cooled rapidly using a fan to the room temperature and then were ground for analysis after being sintered.

\subsection{Test Methods}

\subsubsection{XRD Measurement}

XRD Measurements were carried out by a Bruker AXSD8 Advance (Bruker AXS, Berlin, Germany) with Davinci X-ray $\left(\lambda=1.5406 \AA, 40 \mathrm{kV}\right.$ and $40 \mathrm{~mA}$, scan interval $10^{\circ}-60^{\circ} 2 \theta, 0.01^{\circ}$ and $1 \mathrm{~s}$ per step). The detector was lynxeye linear detector with an opening of $2.94^{\circ}$. The step size was $0.02^{\circ}$ and the measurement time per step was $1 \mathrm{~s}$. EVA software was used for phase determination. 


\subsubsection{Quantitative Phase Analysis and Atomic Site Occupancy Analysis}

Rietveld refinement was employed by TOPAS 4.2 software for quantitative analysis and atomic site occupancy analysis. The Rietveld refinement strategy consisted of emission profile, background, instrument factors and zero error.

In the Rietveld refinement process, $R_{\mathrm{wp}}$ (radiation work permit) was used to evaluate the fitting results as shown in Equation (1). Generally, when $R_{\mathrm{wp}}$ is less than $15 \%$, the result could be considered as reliable [16].

$$
R_{\mathrm{wp}}=\sum\left\{W_{i}\left[\left(y_{i}(\mathrm{obs})-y_{i}(\mathrm{cal})\right)^{2}\right] / \sum w_{i}\left[y_{i}(\mathrm{obs})^{2}\right]\right\}^{1 / 2}
$$

where, $R_{\mathrm{wp}}$ indicates radiation work permit; $y_{i}(\mathrm{obs})$ is the measured diffraction strength at the point $2 \theta_{i}$ in the diffraction pattern; $y_{i}(\mathrm{cal})$ presents the calculated diffraction strength at the point $2 \theta_{i}$ in the diffraction pattern and $w_{i}$ is weighting factor.

Lattice parameters, atomic coordinates, atomic site occupancy and temperature factors were considered in the refinement process.

Replacement rate $(P)$ of Ba ions was introduced as Equation (2).

$$
P=\left[\frac{\mathrm{Ba}_{\mathrm{c}}}{\mathrm{Ba}_{\mathrm{c}}+\mathrm{Ca}_{\mathrm{c}}}\right] \times W_{c}+\left[\frac{\mathrm{Ba}_{\mathrm{o}}}{\mathrm{Ba}_{\mathrm{o}}+\mathrm{Ca}_{\mathrm{o}}}\right] \times W_{o}
$$

where, $P$ presents the replacement rate of $\mathrm{Ba}$ ions; $\mathrm{Ba}_{\mathrm{c}}$ and $\mathrm{Ca}$ are the occupancy rate of $\mathrm{Ba}$ ions and $\mathrm{Ca}$ ions in cubic yeelimite; $\mathrm{Ba}_{o}$ and $\mathrm{Ca}_{o}$ are the occupancy rate of $\mathrm{Ba}$ ions and $\mathrm{Ca}$ ions in orthorhombic yeelimite; $W_{\mathrm{c}}$ and $W_{\mathrm{o}}$ are the percentages of cubic yeelimite and orthorhombic yeelimite, respectively.

The replacement rate $R(\%)$ is defined as Equation (3).

$$
R=(P \times 4) \times 100 \%
$$

where, $R$ presents the replacement rate of $\mathrm{Ba}$ ion; $P$ is the ionic site occupancy of $\mathrm{Ba}$ ion; 4 and 1 present the total cation and the number of $\mathrm{Ba}$ ion in theoretical $\mathrm{Ca}_{3} \mathrm{BaAl}_{6} \mathrm{SO}_{16}$.

\section{Results and Discussion}

\subsection{Qualitative Analysis of Minerals}

The minerals sintered at $1200{ }^{\circ} \mathrm{C}, 1300{ }^{\circ} \mathrm{C}, 1350{ }^{\circ} \mathrm{C}, 1400{ }^{\circ} \mathrm{C}$ and $1440{ }^{\circ} \mathrm{C}$ for different times were analyzed by EVA software. The XRD patterns sintered for $180 \mathrm{~min}$ are shown in Figure 1 and the corresponding COD codes are listed in Table 1.

The diffraction peaks of $\mathrm{CaO}, \mathrm{BaSO}_{4}, \mathrm{Ca}_{3} \mathrm{Al}_{2} \mathrm{O}_{6}, \mathrm{CaAl}_{2} \mathrm{O}_{4}, \mathrm{Ca}_{12} \mathrm{Al}_{14} \mathrm{O}_{33}, \mathrm{BaAl}_{2} \mathrm{O}_{4}, \mathrm{CaSO}_{4}$ are obvious. When the sintering temperature is higher than $1100^{\circ} \mathrm{C}$, mesophases such as $\mathrm{C} 12 \mathrm{~A} 7, \mathrm{CA}, \mathrm{C} 4 \mathrm{~A} 3$ could be formed in the sintering process $[17,18]$. The samples sintered at $1200{ }^{\circ} \mathrm{C}$ (Figure 2) show relatively messy peaks. The characteristic diffraction peaks of CBSA sintered at $1300{ }^{\circ} \mathrm{C}$ are relatively obvious and the characteristic peaks of mesophases decreased. The characteristic peaks of CBSA sintered at $1350{ }^{\circ} \mathrm{C}$ and $1400{ }^{\circ} \mathrm{C}$ are further strengthened and the mesophases reduced. The characteristic peaks of CBSA sintered at $1440{ }^{\circ} \mathrm{C}$ are obvious; however, the characteristic peaks of mesophases begin to increase due to the decomposition of CBSA. 
Table 1. Phase and COD code.

\begin{tabular}{cccc}
\hline Phase & COD code & Phase & COD code \\
\hline CAS-Cubic & 9009938 & $\mathrm{CA}_{2}$ & 3500014 \\
CAS-Orthorhombic & 4001772 & $\mathrm{C}_{4} \mathrm{~A}_{3}$ & 9002486 \\
BA & 1010630 & $\mathrm{C}_{12} \mathrm{~A}_{7}$ & 4308078 \\
BŠ & 1010542 & $\mathrm{CS}$ & 9004096 \\
CA & 1528679 & $\mathrm{C}$ & 1011094 \\
\hline
\end{tabular}

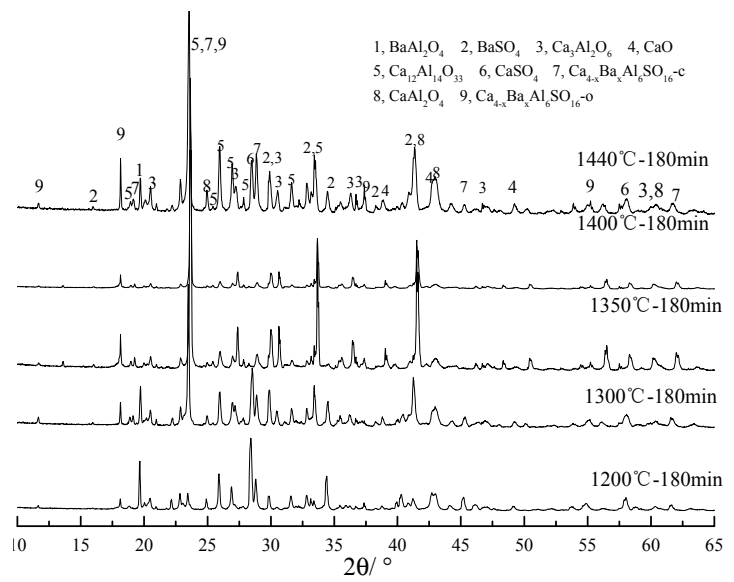

Figure 1. XRD Patterns of calcium barium sulphoaluminate (CBSA) samples sintered at different temperature for $180 \mathrm{~min}$.

\subsection{Quantitative Phase Analysis}

According to the results of qualitative analysis, the structure documents of $\mathrm{CaO}, \mathrm{BaSO}_{4}, \mathrm{Ca}_{3} \mathrm{Al}_{2} \mathrm{O}_{6}$, $\mathrm{CaAl}_{2} \mathrm{O}_{4}, \mathrm{Ca}_{12} \mathrm{Al}_{14} \mathrm{O}_{33}, \mathrm{BaAl}_{2} \mathrm{O}_{4}, \mathrm{CaSO}_{4}$ and $\mathrm{Ca}_{4}-\mathrm{Ba}_{x} \mathrm{Al}_{6} \mathrm{SO}_{16}$ were imported into TOPAS 4.2 software for quantitative analysis. All the phases and corresponding ICSD codes are listed in Table 2. $\mathrm{Ca}_{4}-x \mathrm{Ba}_{x} \mathrm{Al}_{6} \mathrm{SO}_{16}$ is derived from $\mathrm{Ca}_{4} \mathrm{Al}_{6} \mathrm{SO}_{16}$ and there is only a little offset at the diffraction peaks compared with that of $\mathrm{Ca}_{4} \mathrm{Al}_{6} \mathrm{SO}_{16}$. The ICSD code of $\mathrm{Ca}_{4} \mathrm{Al}_{6} \mathrm{SO}_{16}$ was used to refine the structure of $\mathrm{Ca}_{4}-x \mathrm{Ba}_{x} \mathrm{Al}_{6} \mathrm{SO}_{16}$. In the replacement process, the probability that $\mathrm{Ca}^{2+}$ at each position is replaced by $\mathrm{Ba}^{2+}$ is the same. The $\mathrm{R}_{\mathrm{wp}}$ values are all less than 15 , which indicate the quantitative analysis results are reliable.

Table 2. Phases and ICSD codes.

\begin{tabular}{cccc}
\hline Phase & ICSD code & Phase & ICSD code \\
\hline $\mathrm{Ca}_{4} \mathrm{Al}_{6} \mathrm{SO}_{16}-\mathrm{Cubic}$ & 9560 & $\mathrm{CaAl}_{4} \mathrm{O}_{7}$ & 16191 \\
$\mathrm{Ca}_{4} \mathrm{Al}_{6} \mathrm{SO}_{16}-\mathrm{Orthorhombic}$ & 80361 & $\mathrm{Ca}_{12} \mathrm{Al}_{14} \mathrm{O}_{33}$ & 261586 \\
$\mathrm{BaAl}_{2} \mathrm{O}_{4}$ & 246028 & $\mathrm{CaSO}_{4}$ & 183919 \\
$\mathrm{BaO}$ & 186427 & $\mathrm{CaO}$ & 261847 \\
$\mathrm{CaAl}_{2} \mathrm{O}_{4}$ & 180997 & - & - \\
\hline
\end{tabular}

The fitting effect of the sample sintered at $1400{ }^{\circ} \mathrm{C}$ for $180 \mathrm{~min} 1400{ }^{\circ} \mathrm{C}$ is presented in Figure 2 . The result of raw data and fitting data has less error of fitting, it alligns nicely with the value of $R_{\mathrm{wp}}$, which is 8.06. Unit cell parameters of CBSA samples sintered at $1200^{\circ} \mathrm{C}, 1300^{\circ} \mathrm{C}, 1350{ }^{\circ} \mathrm{C}, 1400{ }^{\circ} \mathrm{C}$ for $180 \mathrm{~min}$ 
are presented in Table 3. As Table 3 shows, result of unit cell parameters indicated that the lattice constant increased with increasing sintering temperature. This phenomena can be attributed to the incorporation of $\mathrm{Ba}$ ions into the CSA crystal lattice because the atomic radius of barium is bigger than that of calcium. The same phenomena occurs when the soaking time of the same sintering temperature is increased.

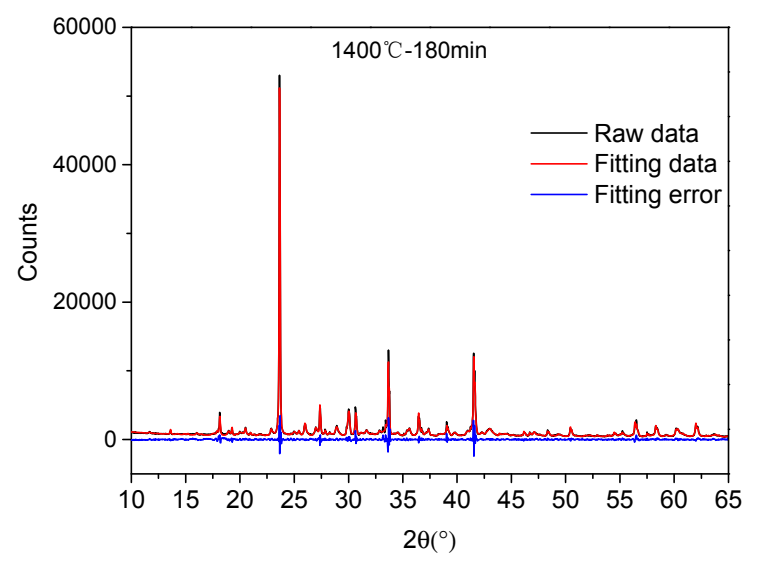

Figure 2. Fitting effect of CBSA samples sintered at $1400{ }^{\circ} \mathrm{C}$ for $180 \mathrm{~min}$.

Table 3. Unit cell parameters of CBSA samples.

\begin{tabular}{|c|c|c|c|c|c|}
\hline Phase & Parameter & $1200^{\circ} \mathrm{C}-180 \mathrm{~min}$ & $1300{ }^{\circ} \mathrm{C}-180 \mathrm{~min}$ & $1350{ }^{\circ} \mathrm{C}-180 \mathrm{~min}$ & $1400{ }^{\circ} \mathrm{C}-180 \mathrm{~min}$ \\
\hline \multirow{3}{*}{ CBSA-O } & $\mathrm{a}$ & 13.01032 & 13.0207508 & 13.0270247 & 13.0402404 \\
\hline & $\mathrm{b}$ & 12.92488 & 12.9469589 & 12.9600426 & 12.9981782 \\
\hline & $\mathrm{c}$ & 9.21658 & 9.22244 & 9.22428 & 9.2330302 \\
\hline CBSA-C & $\mathrm{a}$ & 9.21896 & 9.22475 & 9.23109 & 9.23704 \\
\hline
\end{tabular}

To illustrate the unit cell variation of different $\mathrm{Ba}$ incorporation, one pure CSA with full $\mathrm{Ca}$ content and a second one with half mole of Ba concentration were prepared. As Table 4 shows, $d$ values of the main peak and the second peak were obtained. Phase analysis shows that the distance of crystal face of CBSA increase with the increasing of Ba ion implantation.

Table 4. $d$ value of main peak and second peak.

\begin{tabular}{ccc}
\hline Ba Content & $\begin{array}{c}\text { Main Peak } \\
d \text { value }\end{array}$ & $\begin{array}{c}\text { Second Peak } \\
d \text { value }\end{array}$ \\
\hline 0 & 3.74749 & 2.65358 \\
0.5 & 3.75387 & 2.97368 \\
1.0 & 3.78612 & 3.12588 \\
\hline
\end{tabular}

The total amount of orthorhombic and cubic CBSA is marked as $\mathrm{Ca}_{4-} \mathrm{Ba}_{x} \mathrm{Al}_{6} \mathrm{SO}_{16}$ and the quantitative analysis results are presented in Figure 3.The total amount of $\mathrm{Ca}_{4-} \mathrm{Ba}_{x} \mathrm{Al}_{6} \mathrm{SO}_{16}$ is $40 \%-50 \%$ when the sintering temperature between $1200{ }^{\circ} \mathrm{C}$ and $1300{ }^{\circ} \mathrm{C}$. With the increase of prolonged time, the amount of $\mathrm{Ca}_{4}-x \mathrm{Ba}_{x} \mathrm{Al}_{6} \mathrm{SO}_{16}$ shows a negligible increase rate and the amounts of $\mathrm{CaO}, \mathrm{BaSO}_{4}, \mathrm{Ca}_{3} \mathrm{Al}_{2} \mathrm{O}_{6}$, $\mathrm{CaAl}_{2} \mathrm{O}_{4}, \mathrm{Ca}_{12} \mathrm{Al}_{14} \mathrm{O}_{33}, \mathrm{BaAl}_{2} \mathrm{O}_{4}, \mathrm{CaSO}_{4}$ are relatively large with a total content of over $50 \%$. Gypsum cannot react completely at $1200{ }^{\circ} \mathrm{C}$ and $1300{ }^{\circ} \mathrm{C}$. When the sintering temperature is $1350{ }^{\circ} \mathrm{C}$ and $1400{ }^{\circ} \mathrm{C}$, the proportion of $\mathrm{Ca}_{4-x} \mathrm{Ba}_{x} \mathrm{Al}_{6} \mathrm{SO}_{16}$ is significantly increased; moreover, it increases with the 
increase of prolonged time, and the mesophases are rapidly reduced. When the prolonged time is $180 \mathrm{~min}$ at $1400{ }^{\circ} \mathrm{C}, \mathrm{Ca}_{4}-\mathrm{Ba}_{x} \mathrm{Al}_{6} \mathrm{SO}_{16}$ accounts for approximately $88.4 \%$. However, the amounts of $\mathrm{Ca}_{4}-x \mathrm{Ba}_{x} \mathrm{Al}_{6} \mathrm{SO}_{16}$ decreased at $1440{ }^{\circ} \mathrm{C}$ due to the decomposition. The content of gypsum is less than $1 \%$ when sintered for $180 \mathrm{~min}$ at $1350{ }^{\circ} \mathrm{C}$ and $1400{ }^{\circ} \mathrm{C}$. $\mathrm{CaSO}_{4}$, free $\mathrm{BaO}$ and $\mathrm{CaO}$ formed at $1440{ }^{\circ} \mathrm{C}$ due to the decomposition of CBSA.

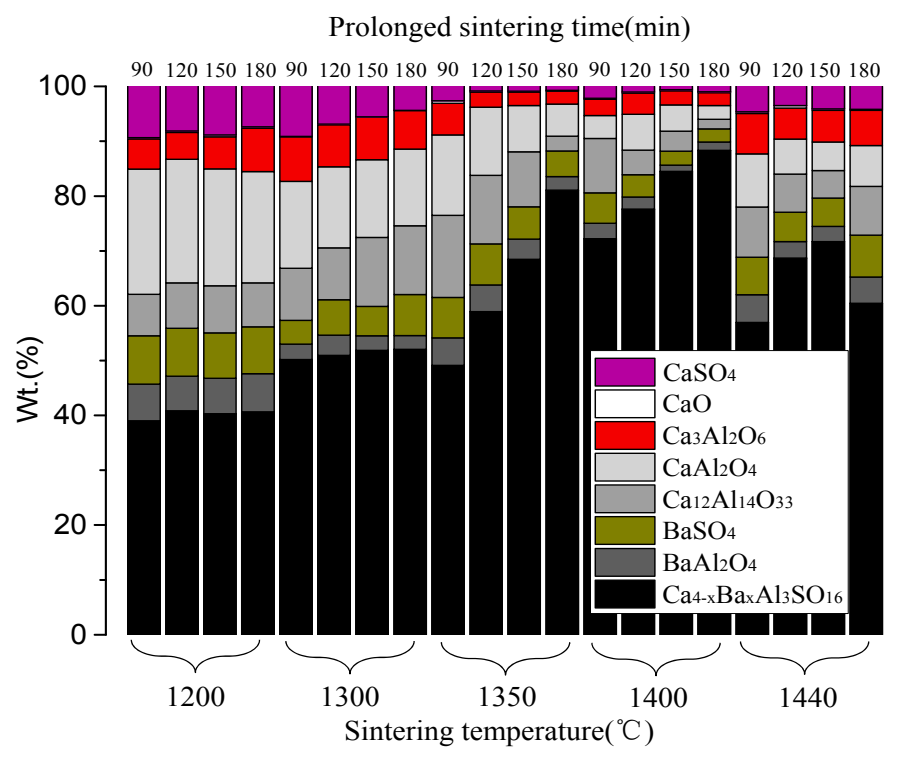

Figure 3. Results of quantitative analysis.

As is shown in Figure 4, the replacement rate of $\mathrm{Ba}^{2+}$ shows serious dependence on the sintering system. It maintained at less than $20 \%$ ignoring the increasing prolonged sintering time when sintered at $1200{ }^{\circ} \mathrm{C}$ and $1300{ }^{\circ} \mathrm{C}$. At relatively low sintering temperature $\left(1200{ }^{\circ} \mathrm{C}\right.$ and $\left.1300{ }^{\circ} \mathrm{C}\right)$, not all the $\mathrm{Ba}^{2+}$ can bound with CSA and the extra $\mathrm{Ba}^{2+}$ exists as other mesophases, such as $\mathrm{BaAl}_{2} \mathrm{O}_{4}, \mathrm{BaSO}_{4}$. The replacement rate of $\mathrm{Ba}^{2+}$ increases with increasing sintering temperature and prolonged sintering time in the $1350-1400{ }^{\circ} \mathrm{C}$ range. In this sintering range, both the content of $\mathrm{Ca}_{4}-x \mathrm{Ba}_{x} \mathrm{Al}_{6} \mathrm{SO}_{16}$ and the replacement rate of $\mathrm{Ba}^{2+}$ increase rapidly. The replacement rate is about $80 \%$ when the sintered at $1400{ }^{\circ} \mathrm{C}$ for $180 \mathrm{~min}$. The replacement rate also decreases due to the decomposition of $\mathrm{Ca}_{-x} \mathrm{Ba}_{x} \mathrm{Al}_{6} \mathrm{SO}_{16}$.

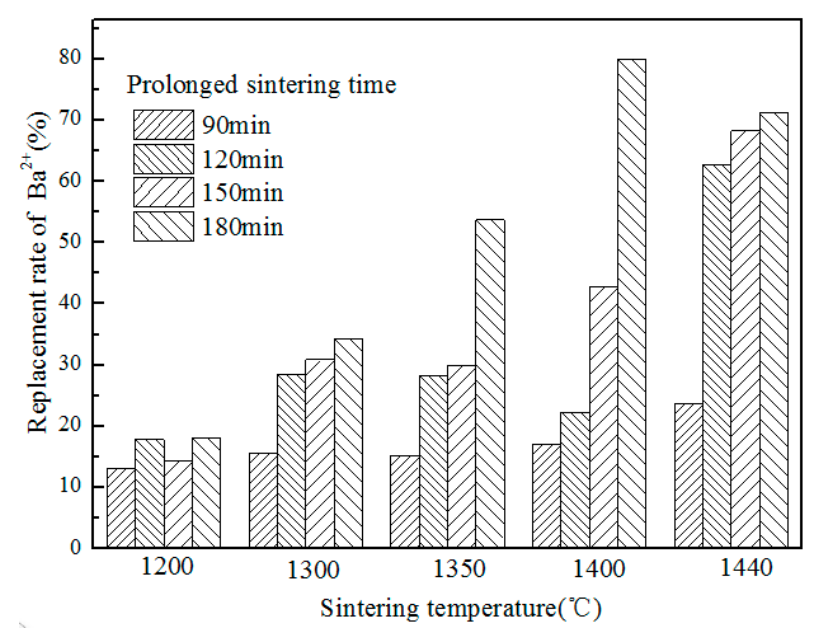

Figure 4. Replacement rate of $\mathrm{Ba}^{2+}$ at different sintering system. 
From the correspondence between the content of $\mathrm{Ca}_{4-x} \mathrm{Ba}_{x} \mathrm{Al}_{6} \mathrm{SO}_{16}$ and replacement rate of $\mathrm{Ba}^{2+}$, the two indexes arrived at the maximum under the same sintering system. Sintering at $1400{ }^{\circ} \mathrm{C}$ for $180 \mathrm{~min}$ is considered the optimum and $\mathrm{Ca} 3.2 \mathrm{Ba} 0.8 \mathrm{Al}_{6} \mathrm{SO}_{16}$ with a content of $88.4 \%$ was synthesized.

\subsection{The Result of Strength}

According to the water-cement ratio $(w / c=0.5)$, we mixed the clinker with the sintering temperature of $1350{ }^{\circ} \mathrm{C}$ and $1400{ }^{\circ} \mathrm{C}$ and put the paste into a $2 \times 2 \times 2 \mathrm{~cm}$ mold by vibration. The specimens are unmolded after being cured in more than $90 \%$ moist air at $20^{\circ} \mathrm{C}$ for 1 day. Then the specimens are cured in standard conditions for measurement of the compressive strength of 3 days and 7 days. The results are shown in Figure 5. We can see that the compressive strength increases with the increase of sintering temperature and the prolonged time.

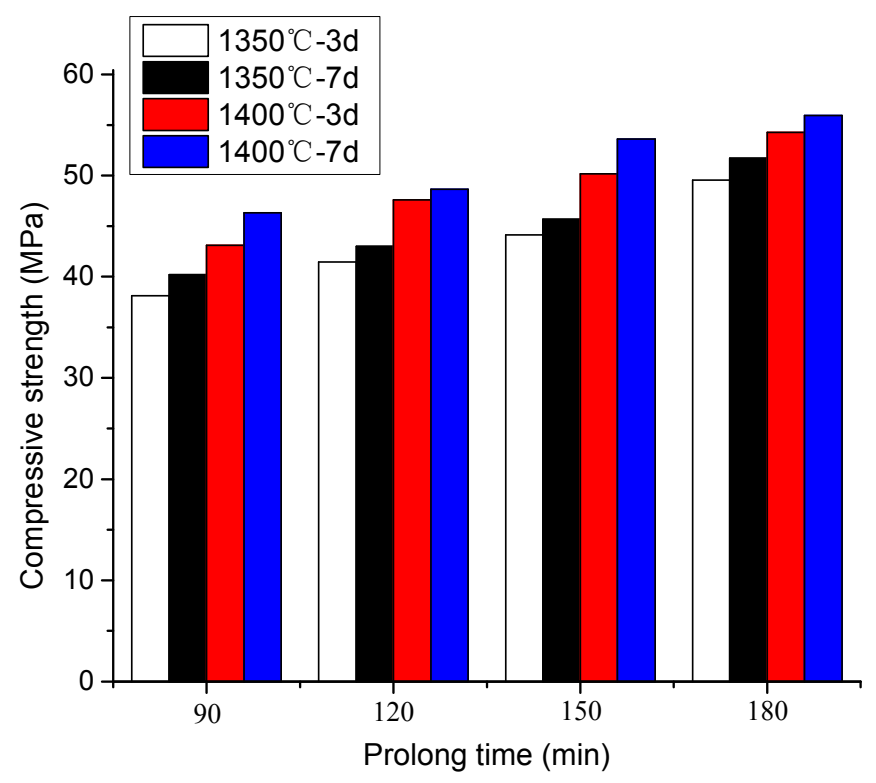

Figure 5. Compressive strength of $1350{ }^{\circ} \mathrm{C}$ and $1400{ }^{\circ} \mathrm{C}$ sintered clinkers.

\section{Conclusions}

(1) In the sintering process of calcium barium sulphoaluminate (CBSA) mineral, except for orthorhombic and cubic CBSA, there also exists mesophases including $\mathrm{CaO}, \mathrm{BaSO}_{4}, \mathrm{Ca}_{3} \mathrm{Al}_{2} \mathrm{O}_{6}$, $\mathrm{CaAl}_{2} \mathrm{O}_{4}, \mathrm{Ca}_{12} \mathrm{Al}_{14} \mathrm{O}_{33}, \mathrm{BaAl}_{2} \mathrm{O}_{4}, \mathrm{CaSO}_{4}$. The content of $\mathrm{CBSA}$ shows serious dependence on the sintering system. When sintered at $1400{ }^{\circ} \mathrm{C}$ for $180 \mathrm{~min}$, the content of CBSA reaches $88.4 \%$. A higher sintering temperature will lead to the decomposition.

(2) Not all the Ba ions can be bounded with CSA in the sintering process. The replacement rate of $\mathrm{Ba}^{2+}$ increased with the increasing sintering temperature and prolonged sintering time and it reached the maximum when sintered at $1400{ }^{\circ} \mathrm{C}$ for $180 \mathrm{~min}$.

(3) Considering the sintering content of CBSA and replacement rate of $\mathrm{Ba}^{2+}$, the best sintering system is a prolonged sintering time of $180 \mathrm{~min}$ at $1400{ }^{\circ} \mathrm{C}$. The sintering content of CBSA is $88.4 \%$ and the replacement rate of $\mathrm{Ba}^{2+}$ is $80 \%$. $\mathrm{Ca}_{3.2} \mathrm{Ba}_{0.8} \mathrm{Al}_{6} \mathrm{SO}_{16}$ was synthesized. 


\section{Acknowledgments}

This work was financed by National Natural Science Foundation of China (51472041).

\section{Author Contributions}

Jun Chang put forward the main ideas of this paper and analyzed experimental results in theory. Xiaopeng Shang constituted and carried out the experiments; Shang also analyzed experimental results with software and wrote paper. All the authors read and approved the final manuscript.

\section{Conflicts of Interest}

The authors declare no conflict of interest.

\section{Reference}

1. Tereanu, I.; Munten, M.; Dragnea, I. Type $3\left(\mathrm{CaO} \cdot \mathrm{Al}_{2} \mathrm{O}_{3}\right) \cdot \mathrm{M}_{x}\left(\mathrm{SO}_{4}\right)_{y}$ compounds and compatibility relations in $\mathrm{CaO}-\mathrm{CaO} \cdot \mathrm{Al}_{2} \mathrm{O}_{3}-\mathrm{M}_{x}\left(\mathrm{SO}_{4}\right)_{y}$ system. Cement 1986, 83, 39-45.

2. Yan, $\mathrm{P}$. Hydration of $\mathrm{Sr}$ and Ba-bearing sulphoaluminates in the presence of sulphates. Adv. Cem. Res. 1993, 5, 65-69.

3. Chang, J. Study on new type Ba-bearing cement. Mater's Thesis, Wuhan University of Technology, Wuhan, China, 1998.

4. Cheng, X.; Chang, J.; Lu, L.; Liu, F.; Teng, B. Study of Ba-bearing calcium sulphoaluminate minerals and cement. Cem. Concr. Res. 2000, 30, 77-81.

5. Young, R.A. The Rietveld Method; Oxford University Press: Oxford, UK, 1993; pp. 21-22.

6. Halstead, P.E.; Moore, A.E. The composition and crystallography of an anhydrous calcium aluminosulphate occurring in expanding cement. J. Appl. Chem. 1962, 12, 413-417.

7. Saalfeld, H.; Depmeier, W. Silicon-free compounds with sodalite structure. Krist. Tech. 1972, 7, 229-233.

8. Calos, N.J.; Kennard, C.H.L.; Whittaker, A.K.; Davis, R.L. Structure of calcium aluminate sulfate $\mathrm{Ca}_{4} \mathrm{Al}_{6} \mathrm{O}_{16}$ S. J. Solid State Chem. 1995, 119, 1-7.

9. Zhang, P.; Chen, Y.; Shi, P.; Wang, J. The crystal structure of $\mathrm{C}_{4} \mathrm{~A}_{3} \mathrm{~S}$. In Proceedings of 9th International Congress on the Chemistry of Cement, New Delhi, India, 23-28 November 1992; 201-208.

10. Krstanović, I.; Radaković, A.; Karanović, L. X-Ray Powder Data for $\mathrm{Ca}_{4} \mathrm{Al}_{6} \mathrm{O}_{12} \mathrm{SO}_{4}$. Powder Diffr. 1992, 7, 47-48.

11. Hargis, C.W.; Moon, J.; Lothenbach, B.; Winnefeld, F.; Wenk, H.R.; Monterio, P.J. Calcium Sulfoaluminate Sodalite $\left(\mathrm{Ca}_{4} \mathrm{Al}_{6} \mathrm{O}_{12} \mathrm{SO}_{4}\right)$ Crystal Structure Evaluation and Bulk Modulus Determination. J. Am. Ceram. Soc. 2014, 97, 892-898.

12. Cuesta, A.; de La Torre, A.G.; Losilla, E.R.; Peterson, V.K.; Rejmak, P.; Ayuela, A.; Aranda, M.A. Structure, atomistic simulations, and phase transition of stoichiometric yeelimite. Chem. Mater. 2013, 9, 1680-1687.

13. Cuesta, A.; de La Torre, A.G.; Losilla, E.R.; Santacruz, I.; Aranda, M.A. Pseudo cubic crystal structure and phase transition in doped yeelimite. Cryst. Growth Des. 2014, 10, 5158-5163. 
14. Andac, O.; Glasser, F.P. Polymorphism of calcium sulphoaluminate $\left(\mathrm{Ca}_{4} \mathrm{Al}_{6} \mathrm{O}_{16} \mathrm{SO}_{3}\right)$ and its solid solutions. Adv. Cem. Res. 1994, 22, 57-60.

15. Álvarez-Pinazo, G.; Cuesta, A.; García-Maté, M.; Santacruz, I.; Losilla, E.R.; de La Torre, A.G.; Aranda, M.A. Rietveld quantitative phase analysis of Yeelimite-containing cements. Cem. Concr. Res. 2012, 7, 960-971.

16. Jansen, E.; Schäfer, W.; Will, G. R values in analysis of powder diffraction data using Rietveld refinement. J. Appl. Crystallogr. 1994, 4, 492-496.

17. Ma, S.; Shen, X.; Huang, Y.; Huang, Y.; Zhong, B. Preparation and formation mechanism of calcium sulphoaluminate. J. Ceram. Soc. 2008, 1, 78-81.

18. Zhang, W.; Ouyang, S.; Chen, Y. Study on the compound formation in system $\mathrm{CaO}-\mathrm{Al}_{2} \mathrm{O}_{3}-\mathrm{BaSO}_{4}$ and the formation kinetics of $3 \mathrm{CaO}_{3} \cdot \mathrm{Al}_{2} \mathrm{O}_{3} \cdot \mathrm{BaSO}_{4}$. J. Chin. Ceram. Soc. 2001, 4, 305-308.

(C) 2015 by the authors; licensee MDPI, Basel, Switzerland. This article is an open access article distributed under the terms and conditions of the Creative Commons Attribution license (http://creativecommons.org/licenses/by/4.0/). 